\title{
Effects of zearalenone on the localization and expression of the growth hormone receptor gene in the uteri of post-weaning piglets
}

\author{
Min Zhou ${ }^{1}$, Li Jie Yang ${ }^{1}$, Wei Ren Yang ${ }^{1}$, Li Bo Huang ${ }^{1}$, Xue Mei Zhou ${ }^{1}$, \\ Shu Zhen Jiang ${ }^{1, *}$, and Zai Bin Yang ${ }^{1, *}$
}

\author{
* Corresponding Authors: \\ Shu Zhen Jiang \\ Tel: +86-18653817377, Fax: +86-538-8249371, \\ E-mail: shuzhen305@163.com \\ Zai Bin Yang \\ Tel: +86-18605383389, Fax: +86-538-8249371, \\ E-mail: yzb204@163.com
}

${ }^{1}$ Department of Animal Sciences and Technology and Shandong Provincial Key Laboratory of Animal Biotechnology and Disease Control and Prevention, Shandong Agricultural University, Taian, Shandong 271018, China

ORCID

Min Zhou

https://orcid.org/0000-0003-0425-7893

Li Jie Yang

https://orcid.org/0000-0001-7601-2049

Wei Ren Yang

https://orcid.org/0000-0002-9363-0516

Li Bo Huang

https://orcid.org/0000-0002-5517-8493

Xue Mei Zhou

https://orcid.org/0000-0001-6119-3991

Shu Zhen Jiang

https://orcid.org/0000-0002-4943-0322

Zai Bin Yang

https://orcid.org/0000-0001-8757-9120

Submitted Jul 20, 2017; Revised Aug 29, 2017; Accepted Sept 15, 2017
Objective: In this study, we investigated the adverse effects of dietary zearalenone (ZEA) (0.5 to $1.5 \mathrm{mg} / \mathrm{kg}$ diet) on the localization and expression of the growth hormone receptor (GHR) in the uteri of post-weaning gilts and explored alternative mechanism of the reproductive toxicity of ZEA on piglets.

Methods: A total of forty healthy piglets (Duroc $\times$ Landrace $\times$ Large White) aged $28 \mathrm{~d}$ were selected for study. Piglets were transferred to single cages after 10 days' adaptation on an obstetric table. The animals were allocated to one of four treatments: a normal basal diet supplemented with 0 (Control), 0.5 (ZEA0.5), 1.0 (ZEA1.0), or 1.5 (ZEA1.5) $\mathrm{mg} / \mathrm{kg}$ purified ZEA, and fed for $35 \mathrm{~d}$ after the 10- $\mathrm{d}$ adaptation. Analyzed ZEA concentrations in the diets were $0,0.52 \pm 0.07$, $1.04 \pm 0.03$, and $1.51 \pm 0.13 \mathrm{mg} / \mathrm{kg}$, respectively. At the end of the feeding trial, piglets were euthanized after being fasted for $12 \mathrm{~h}$. Two samples of uterine tissue from each pig were rapidly collected, one of which was stored at $-80^{\circ} \mathrm{C}$ for analysis of the relative mRNA and protein expression of GHR, and the second was promptly fixed in Bouin's solution for immunohistochemical analysis. Results: The relative weight of the uteri and thickness of the myometrium and endometrium increased linearly $(\mathrm{p}<0.001)$ and quadratically $(\mathrm{p}<0.001)$ with an increasing level of ZEA. The results of immunohistochemical analysis indicated that GHR immunoreactive substance was mainly localizated in the cytoplasm of uterine smooth muscle, glandular epithelial, luminal epithelial, stromal, and vascular endothelial cells. In contrast, nuclear staining was rarely observed. The immunoreactive integrated optic density of GHR in the myometrium, luminal epithelium, glandular epithelium, and whole uteri of weaning gilts increased linearly $(\mathrm{p}<0.001)$ and quadratically $(\mathrm{p}<0.05)$ with an increasing level of ZEA. The mRNA and protein expression of GHR in the uteri of weaning gilts increased linearly $(\mathrm{p}<0.001)$ and quadratically $(\mathrm{p}<0.05)$ with an increasing level of ZEA.

Conclusion: In conclusion, ZEA at a concentration of $0.5 \mathrm{mg} / \mathrm{kg}$ was sufficient to significantly thicken the myometrium and endometrium, and at a concentration of $1.0 \mathrm{mg} / \mathrm{kg}$ induced a high level of GHR expression to promote growth and development of the uteri. This revealed an alternative molecular mechanism whereby ZEA induces growth and development of the uteri and provides a theoretical basis for the revision of Chinese feed hygiene standards.

Keywords: Zearalenone; Uteri; Growth Hormone Receptor; mRNA; Protein

\section{INTRODUCTION}

The mycotoxin zearalenone (ZEA) is an estrogenic metabolite produced by a variety of species of Fusarium and Gibberella molds [1-4]. ZEA is commonly found in grain crops (e.g., corn, barley, sorghum, rye, and wheat) and feeds originated from animal sources (e.g., meat and dairy products) $[5,6]$. It has previously been reported that severe contamination of grain, processed grain byproducts, and feed with ZEA occurs in numerous areas of the world [7,8]. Pigs, and in particular female pigs, are sensitive to ZEA [9], and the European Committee has limited its concentration 
to $0.1 \mathrm{mg} / \mathrm{kg}$ in piglet diets [10], whereas in China, the maximum limit of ZEA in diets is $0.5 \mathrm{mg} / \mathrm{kg}$ [11]. This mycotoxin as well as its main metabolites, including $\alpha$-zearalenol ( $\alpha$-zol), $\beta$-zearalenol ( $\beta$-zol), $\alpha$-zearalanol ( $\alpha$-zel), and $\beta$-zearalanol ( $\beta$-zel), have been shown to have estrogenic activity due to their structural similarity to $17 \beta$-estradiol [12-14]. Research has shown that 50 to $100 \mathrm{mg} / \mathrm{kg}$ ZEA in diets can cause typical clinical symptoms, including swollen vulva and vaginal prolapse, and also reproductive disorders such as ovarian abnormalities, pseudopregnancy, infertility, miscarriage, and false estrus in sows [15]. Diets supplemented with $1.1,2.0$, and $3.2 \mathrm{mg} / \mathrm{kg}$ ZEA have been shown to increase the index of reproductive organs in piglets, stimulate swelling of the vulva, and alter the structure of the uteri and ovaries [14].

Growth hormone (GH), a single-chain polypeptide hormone secreted by the pituitary gland of animals, plays an indispensable role in the growth and metabolism of the body by regulating the metabolism of carbohydrates, lipids, and proteins [16,17]. As the main hormone of the growth axis, GH plays an important role in regulating the growth and development of animals [18]. Growth hormone receptor (GHR) is the receptor protein of GH. As a biological macromolecule, GH must combine with GHR on the target cell membrane and transfer information to the cell through a dielectric conductor to fulfil its biological function [19]. Although there have been many reports on the expression of GHR in the uteri during the estrous cycle of rats [20], pigs [21], and sheep [22], there is little information available on the negative effect of low concentrations of ZEA ( 0.5 to $1.5 \mathrm{mg} / \mathrm{kg}$ ) on the localization and expression of the GHR in post-weaning piglets. In the present study, we therefore sought to examine whether feeding a ZEAcontaminated $(0.5,1.0$, and $1.5 \mathrm{mg} / \mathrm{kg})$ diet to post-weaning piglets would influence of the localization of GHR, and affect GHR mRNA and protein expressions.

\section{MATERIALS AND METHODS}

\section{Preparation of zearalenone-contaminated diet}

Purified crystalline ZEA (Fermentek, Jerusalem, Israel) was dissolved in acetic ether and then poured onto talcum powder. The material was left overnight to allow acetic ether evaporation and a ZEA premix of $1,000 \mathrm{mg} / \mathrm{kg}$ was subsequently prepared. This premix was then diluted to $10 \mathrm{mg} / \mathrm{kg}$ ZEA premix with toxin-free corn meal. The experimental diets were formulated with $10 \mathrm{mg} / \mathrm{kg}$ ZEA premix instead of corn and talcum powder carrier according to the required level of ZEA and stored in covered containers. The doses of ZEA $(0,0.5,1.0$, and $1.5 \mathrm{mg} / \mathrm{kg})$ used in the present study were based on the results of Jiang et al [14], Chen et al [23], and Dai et al [24]. Experimental diet preparation was completed a week before conducting the trial. The toxin levels in the diet were examined immediately by the Qingdao Entry Exit Inspection and Quarantine Bureau after sampling before and at the end of the feeding experiment. Deoxynivalenol (DON) was analyzed using high-performance liquid chromatography and an enzyme- linked immunosorbent assay, and fluorescent techniques were used to measure ZEA, fumonisins (FUM), and aflatoxin (AFL) levels. The detection limits for AFL, ZEA, DON, and FUM were $1.0 \mu \mathrm{g} / \mathrm{kg}, 0.1 \mathrm{mg} / \mathrm{kg}, 0.1 \mathrm{mg} / \mathrm{kg}$, and $0.25 \mathrm{mg} / \mathrm{kg}$, respectively.

\section{Experimental design, female piglets, and management} The piglets used in all experiments were cared for in accordance with the guidelines for the care and use of laboratory animals prescribed by the Animal Nutrition Research Institute of Shandong Agricultural University and the Ministry of Agriculture of China. A total of 40 healthy post-weaning piglets (Duroc $\times$ Landrace $\times$ Large White) aged $28 \mathrm{~d}$ were selected for this study. After 10 days' adaptation on an obstetric table, piglets were transferred to single cages $\left(0.48 \mathrm{~m}^{2}\right)$ fitted with a plastic slatted floor and nipple drinker. The animals were then allocated to one of four treatments. Each treatment consisted of 10 replicates of one pig per replicate according to the average body weight $14.01 \pm 0.86$ $\mathrm{kg}$ (mean \pm standard deviation [SD]). Piglets were fed a basal diet according to NRC [25] (Table 1) supplemented with 0 (Control), 0.5 (ZEA0.5), 1.0 (ZEA1.0), or 1.5 (ZEA1.5) mg/kg purified ZEA for $35 \mathrm{~d}$ after the 10-d adaptation. Analyzed ZEA concentrations in the diets were $0,0.52 \pm 0.07,1.04 \pm 0.03$, and $1.51 \pm 0.13 \mathrm{mg} / \mathrm{kg}$, respectively. In all treatment diets, no other toxins were detected.

Table 1. Ingredients and nutrient levels of the basal diet (air dry basis) ${ }^{1)}$

\begin{tabular}{|c|c|}
\hline Item & \\
\hline \multicolumn{2}{|l|}{ Ingredients } \\
\hline Corn $(\%)$ & 64.5 \\
\hline Whey powder (\%) & 5.0 \\
\hline Soybean meal (\%) & 23.0 \\
\hline Fish meal $(\%)$ & 5.0 \\
\hline L-lysine $\mathrm{HCl}(\%)$ & 0.2 \\
\hline $\mathrm{CaHPO}_{4}(\%)$ & 0.7 \\
\hline Pulverized limestone (\%) & 0.3 \\
\hline $\mathrm{NaCl}(\%)$ & 0.3 \\
\hline Premix $(\%)$ & 1.0 \\
\hline Total & 100.0 \\
\hline \multicolumn{2}{|l|}{ Nutrients ${ }^{3)}$} \\
\hline Digestible energy (MJ/kg) & 13.81 \\
\hline Crude protein $(\%)$ & 19.82 \\
\hline Calcium (\%) & 0.70 \\
\hline Total phosphorus (\%) & 0.64 \\
\hline Lysine $(\%)$ & 1.22 \\
\hline Sulfur amino acid (\%) & 0.65 \\
\hline Threonine (\%) & 0.75 \\
\hline Trptophan (\%) & 0.22 \\
\hline \multicolumn{2}{|c|}{$\begin{array}{l}\text { ZEA, zearalenone. } \\
\text { 1) Treatments were basal diet supplemented with purified ZEA at the level of } 0,0.5,1.0 \\
\text { or } 1.5 \mathrm{mg} / \mathrm{kg} \text {, with analyzed ZEA concentrations of } 0,0.52 \pm 0.07,1.04 \pm 0.03 \text {, and } \\
1.51 \pm 0.13 \mathrm{mg} / \mathrm{kg} \text {, respectively. } \\
\text { 2) Supplied per kg of diet: Vit A } 3,300 \mathrm{IU}, \text { Vit } \mathrm{D}_{3} 330 \mathrm{IU} \text {, Vit E } 24 \mathrm{IU}, \text { Vit } \mathrm{K}_{3} 0.75 \mathrm{mg} \text {, Vit } \\
\mathrm{B}_{1} 1.50 \mathrm{mg} \text {, Vit } \mathrm{B}_{2} 5.25 \mathrm{mg} \text {, Vit } \mathrm{B}_{12} 0.026 \mathrm{mg} \text {, pantothenic acid } 15.00 \mathrm{mg} \text {, niacin } 22.50 \\
\mathrm{mg} \text {, biotin } 0.075 \mathrm{mg} \text {, olic acid } 0.45 \mathrm{mg}, \mathrm{Mn} 6.00 \mathrm{mg} \text {, Fe } 150 \mathrm{mg}, Z \mathrm{n} 150 \mathrm{mg} \text {, Cu } 9.00 \\
\mathrm{mg} \text { I } 0.21 \mathrm{mg} \text {, Se } 0.45 \mathrm{mg} \text {. } \\
\text { 3) Digestible energy was the calculated value, and the other nutrient levels were analyzed } \\
\text { value. }\end{array}$} \\
\hline
\end{tabular}


Representative samples of feed were taken at the beginning and end of the experimental period for nutrient analyses according to the methods described by the AOAC [26]. The animal feeding experiment was carried out in the Animal Nutrition Research Institute of Shandong Agricultural University of China. Before the start of the experiment, the pigs' cages and the surrounding environment were cleaned and disinfected. During the first week of the experiment, the room temperature was maintained at $30^{\circ} \mathrm{C}$, and was thereafter maintained at $26^{\circ} \mathrm{C}$ to $28^{\circ} \mathrm{C}$. The relative humidity was approximately $65 \%$.

\section{Sample collection}

At the end of the feeding trial, piglets were euthanized after being fasted for $12 \mathrm{~h}$. Uteri were then rapidly isolated from the surrounding fat and tissue under sterile conditions and weighed to calculate the relative weight (relative weight of uteri $[\mathrm{g} / \mathrm{kg}]=$ uterine weight/live pig weight). Two samples of uterine tissue from each pig were rapidly collected, one of which was collected in an RNase-free 2-mL frozen tube and placed in liquid nitrogen, and then stored at $-80^{\circ} \mathrm{C}$ for subsequent analysis of the relative mRNA expression of GHR. The second sample was promptly fixed in Bouin's solution for immunohistochemical analysis. Following fixation, 5- $\mu \mathrm{m}$ sections were cut on a Leica RM 2235 microtome (Leica, Germany), mounted on poly-L-lysine-coated glass slides, and dried overnight at $37^{\circ} \mathrm{C}$ prior to routine staining for immunohistochemical analysis.

\section{Immunohistochemistry}

Sections were dewaxed and rehydrated, and antigen retrieval was performed in sodium citrate buffer ( $0.01 \mathrm{~mol} / \mathrm{L}, \mathrm{pH} 6.0)$ using a microwave unit for $20 \mathrm{~min}$ at full power. The sections were then washed ( $3 \times 5 \mathrm{~min}$ ) with phosphate buffer saline (PBS) $(0.01 \mathrm{~mol} / \mathrm{L}$, $\mathrm{pH}$ 7.2). Endogenous peroxidase activity was blocked by incubating sections in $10 \%$ hydrogen peroxide $\left(\mathrm{H}_{2} \mathrm{O}_{2}\right)$ for $1.5 \mathrm{~h}$. To block nonspecific binding, sections were incubated for $1 \mathrm{~h}$ in $10 \%$ normal goat serum (ZSGB-BIO, Beijing, China). Immunohistochemical analysis was conducted according to kit instructions (Histostain-SP Kits for rabbit primary antibody, SPN-9001, ZSGB$\mathrm{BIO}$, Beijing, China). After washing with PBS, the sections were incubated overnight with polyclonal rabbit antibody GHR (1:80, bs-0654R, BIOSS, Beijing, China) at $4^{\circ} \mathrm{C}$. The following day, the sections were washed with PBS and were subsequently incubated with biotinylated secondary antibody (anti-rabbit immunoglobulin $\mathrm{G}$ [IgG]; $1: 150$ ) for $2 \mathrm{~h}$ at $37^{\circ} \mathrm{C}$, and then incubated with horseradish peroxidase label (1:150) for $1 \mathrm{~h}$. The sections were subsequently washed with PBS, followed by immersion in diaminobenzidine tetrachloride (DAB kit, TIANGEN PA110, Beijing, China) for 1 to $3 \mathrm{~min}$ to detect immunostaining. The sections were counterstained with hematoxylin, followed by color separation with acid alcohol, and then submerged in tap water until the sections turned blue. The sections were then dehydrated, sealed in clear resin, mounted, and observed microscopically for the distribution of positive cells using a bright field of view.

Measurement of the integrated optical density of the growth hormone receptor immunohistochemistry Histological sections of the uteri were observed using a microscope (Nikon ELIPSE 80i, Tokyo, Japan) at magnifications of $\times 40$, $\times 100$, and $\times 200$. To evaluate the amount of cell staining and quantity of the target antigen of GHR, the images were analyzed using image analysis software (Image Pro-Plus 6.0, Media Cybernetics, Sliver Spring, MD, USA). This yielded values of the total crosssectional integrated optical density (IOD) [27], which were used to compare the amount of GHR staining in different parts of the uteri of GHR in the different treatments. We examined at least five stained sections, which were randomly selected from the 10 piglets in each group.

Total RNA extraction, cDNA preparation, and quantitative real-time reverse transcription polymerase chain reaction Total RNA was extracted from piglet uteri using RNAiso Plus (Applied TaKaRa, DaLian, China), following the manufacturer's directions. The purity and concentration of the RNA was assessed using an Eppendorf Biophotometer (Eppendorf, RS323C, Leipzig, Germany) at an absorbance ratio of $260 / 280 \mathrm{~nm}$ (values in the range 1.8 to 2.0 indicate a pure RNA sample). RNA integrity was verified by agarose gel electrophoresis. Total RNA was reverse transcribed to cDNA using a Reverse Transcription System kit (PrimeScript RT Master Mix, RR036A, Applied TaKaRa, China).

For quantitative real-time reverse transcription polymerase chain reaction (qRT-PCR), the total volume of the PCR reaction mixture was $20 \mu \mathrm{L}$, which contained SYBR Premix Ex Taq-TIi RNaseH Plus (TaKara code: RR420A, Lot: AK7502, China). Each sample was analyzed in three replicates. The optimized qRT-PCR protocol included an initial denaturation step at $95^{\circ} \mathrm{C}$ for $30 \mathrm{~s}$, followed by 43 cycles at $95^{\circ} \mathrm{C}$ for $5 \mathrm{~s}, 60^{\circ} \mathrm{C}$ for $34 \mathrm{~s}, 95^{\circ} \mathrm{C}$ for 15 $\mathrm{s}$, and $60^{\circ} \mathrm{C}$ for $60 \mathrm{~s}$, with a final step at $95^{\circ} \mathrm{C}$ for $15 \mathrm{~s}$. The qRTPCR reactions were conducted in an ABI 7500 Real Time PCR System (Applied Biosystems, Foster, CA, USA). The relative amounts of GHR mRNA were expressed and calculated as being equal to $2-\Delta \Delta \mathrm{CT}$ [28]. The primer sequences and product lengths are presented in Table 2.

\section{Western blotting}

The total protein of uterine tissue was extracted by the lysate in-

Table 2. Primer sequences of the growth hormone receptor (GHR) and glyceraldehyde3-phosphate dehydrogenase (GAPDH)

\begin{tabular}{cccc}
\hline $\begin{array}{c}\text { Target } \\
\text { gene }\end{array}$ & Accession No. & \multicolumn{1}{c}{ Primer sequence (5' to 3') } & $\begin{array}{c}\text { Product } \\
\text { size (bp) }\end{array}$ \\
\hline GHR & DQ_106869.1 & F: CCTCAACTGGACTCTACTG & 228 \\
& R:ACACGCACTTCATACTCTT & \\
GAPDH & NM_001206359.1 & $\begin{array}{l}\text { F:ATGGTGAAGGTCGGAGTGAA } \\
\text { R:CGTGGGGGATCATACTGG }\end{array}$ & 154 \\
\hline
\end{tabular}


structions (containing phenylmethanesulfonyl fluoride [PMSF], Beyotime, Shanghai, China) and detected using a BCA protein assay kit (Tiangen Biotech, China). The sample size was $50 \mu \mathrm{g}$ protein per sample. Samples were separated by electrophoresis on polyacrylamide gels, and were subsequently transferred to nitrocellulose membranes. The membranes were incubated in $5 \%$ skimmed milk powder for $2 \mathrm{~h}$, and then washed with Tris buffered saline Tween (TBST) (pH 7.6) ( $3 \times 10 \mathrm{~min})$, followed by addition of the primary antibody (polyclonal rabbit anti GHR, 1:300 (diluted by primary antibody dilution buffer, Beyotime, China), BIOSS, Beijing; monoclonal anti Actin, 1:1,000, Beyotime, China) and incubated at $4^{\circ} \mathrm{C}$ overnight. After washing with TBST, the nitrocellulose membranes were then incubated with anti-rabbit IgG antibody (1:3,000 [diluted by secondary antibody dilution buffer, Beyotime, China]; CWBIO) and anti-mouse IgG (1:3,000 [diluted by secondary antibody dilution buffer, Beyotime, China]; CWBIO) for $2.5 \mathrm{~h}$ at $37^{\circ} \mathrm{C}$. Following washing with TBST, membranes were immersed in a high-sensitivity luminescence reagent (BeyoECL Plus, Beyotime, China), exposed to film using FusionCapt Advance FX7 (Fusion FX, OSTC), and analyzed using Ipp 6.0 (Image Pro-Plus 6.0, Media Cybernetics, USA).

\section{Statistical analysis}

Data of relative weight, myometrial and endometrial thickness, IOD, and GHR mRNA and protein expression were subjected to analysis of variance using the general linear model procedure of SAS 9.2. The data were initially analyzed as a completely randomized design with individual piglets as random factors to examine the overall effect of treatments. Orthogonal polynomial contrasts were then used to determine linear and quadratic responses to the ZEA levels of treatments. Significant differences among treatments were further analyzed using Duncan's multiple range tests. Data were expressed as the mean $\pm \mathrm{SD}$. All statements of significance are based on a probability of $\mathrm{p}<0.05$.

\section{RESULTS}

\section{The relative weight of the uteri and thickness of the} myometrium and endometrum

Results of the relative weight of the uteri and thickness of the myometrium and endometrium are shown in Table 3. The relative weight of the uteri and the thickness of the myometrium and endometrium showed significant linear $(\mathrm{p}<0.001)$ and quadratic $(\mathrm{p}<0.001)$ increases with an increasing level of ZEA. The relative weight of the uteri in the ZEA1.5 treatment was significantly higher than that in the ZEA1.0 treatment $(\mathrm{p}<0.05)$, and that in the ZEA1.0 treatment was significantly higher than that in the control and ZEA0.5 treatments $(\mathrm{p}<0.05)$. The thickness of the myometrium and endometrium in the ZEA1.5 treatment was significantly higher than that in the ZEA1.0 treatment $(\mathrm{p}<0.05)$, whereas that in the ZEA1.0 treatment was significantly higher than that in the ZEA0.5 treatment $(\mathrm{p}<0.05)$, and that in the ZEA0.5
Table 3. Effects of zearalenone (ZEA) on relative weight and myometrial and endometrial thickness measured in 100 times of the uteri in post-weaning piglets

\begin{tabular}{|c|c|c|c|c|}
\hline Items ${ }^{1)}$ & & Uteri (g/kg) & $\begin{array}{c}\text { Myometrial } \\
\text { thickness }(\mathrm{mm})\end{array}$ & $\begin{array}{c}\text { Endometrial } \\
\text { thickness (mm) }\end{array}$ \\
\hline Control & & $1.12 \pm 0.09^{c}$ & $0.91 \pm 0.02^{d}$ & $1.85 \pm 0.17^{d}$ \\
\hline ZEA0.5 & & $1.17 \pm 0.11^{c}$ & $1.28 \pm 0.07^{c}$ & $2.27 \pm 0.15^{c}$ \\
\hline ZEA1.0 & & $1.69 \pm 0.13^{b}$ & $1.73 \pm 0.05^{b}$ & $2.54 \pm 0.11^{b}$ \\
\hline ZEA1.5 & & $1.97 \pm 0.15^{\mathrm{a}}$ & $1.91 \pm 0.10^{\mathrm{a}}$ & $2.81 \pm 0.22^{\mathrm{a}}$ \\
\hline \multirow[t]{3}{*}{$p$-values } & Treatment & $<0.001$ & $<0.001$ & $<0.001$ \\
\hline & Linear & $<0.001$ & $<0.001$ & $<0.001$ \\
\hline & Quadratic & $<0.001$ & $<0.001$ & $<0.001$ \\
\hline
\end{tabular}

1) Control, ZEA0.5, ZEA1.0, and ZEA1.5 represent the control diet with an addition of 0 , $0.5,1.0$, and $1.5 \mathrm{mg} / \mathrm{kg} Z \mathrm{ZEA}$, and with analyzed ZEA concentrations of $0,0.52 \pm 0.07$, $1.04 \pm 0.03$, and $1.51 \pm 0.13 \mathrm{mg} / \mathrm{kg}$, respectively.

${ }^{a-d}$ Values with a column with the different letters mean significantly different $(p<0.05)$.

treatment was significantly higher than that in the control $(\mathrm{p}<0.05)$.

\section{The localization of the growth hormone receptor}

The effects of ZEA on GHR localization in the uteri of postweaning gilts are shown in Figure 1. The results of immunohistochemistry indicated that GHR immunoreactive substance was mainly localized in the cytoplasm of smooth muscle cells (M), glandular epithelial cells $(G)$, luminal epithelial cells (LE), stromal cells $(\mathrm{S})$, and vascular endothelial cells $(\mathrm{V})$ in the uteri of piglets. In contrast, nuclear staining was rarely observed. A light yellow immunoreactive substance was observed in the control. The localization pattern of GHR-positive substances in the ZEA-treated pigs was essentially the same as that in the control group (the arrows); however, compared with the control, the positive reaction of GHR was enhanced (A1-B1-C1-D1 and A4-B4-C4-D4), and block localization of yellow and brown immunoreactive substances was observed with an increasing level of ZEA (A2B2-C2-D2).

\section{Immunoreactive integrated optic density of the growth} hormone receptor

The IOD of GHR in the myometrium, luminal epithelium, glandular epithelium, and whole uteri of weaning gilts showed significant linear $(\mathrm{p}<0.001)$ and quadratic $(\mathrm{p}<0.05)$ increases with an increasing level of ZEA (Table 4). In general, the IOD of the ZEA1.5 treatment was significantly higher than that of the ZEA1.0 treatment $(p<0.05)$, and that of the ZEA1.0 treatment was significantly higher than that of the ZEA0.5 and control treatments $(\mathrm{p}<0.05)$. The IOD values for the myometrium, luminal epithelium, and glandular epithelium in the ZEA1.5 treatment were significantly higher than those of the ZEA1.0 treatment $(\mathrm{p}<0.05)$, whereas the IOD values for the myometrium, luminal epithelium, and glandular epithelium in the ZEA1.0 treatment were significantly higher than those of the ZEA0.5 treatment $(\mathrm{p}<0.05)$, and the IOD values of the myometrium and glandular epithelium in the ZEA0.5 treatment were significantly higher than those of the control $(\mathrm{p}<0.05)$. 

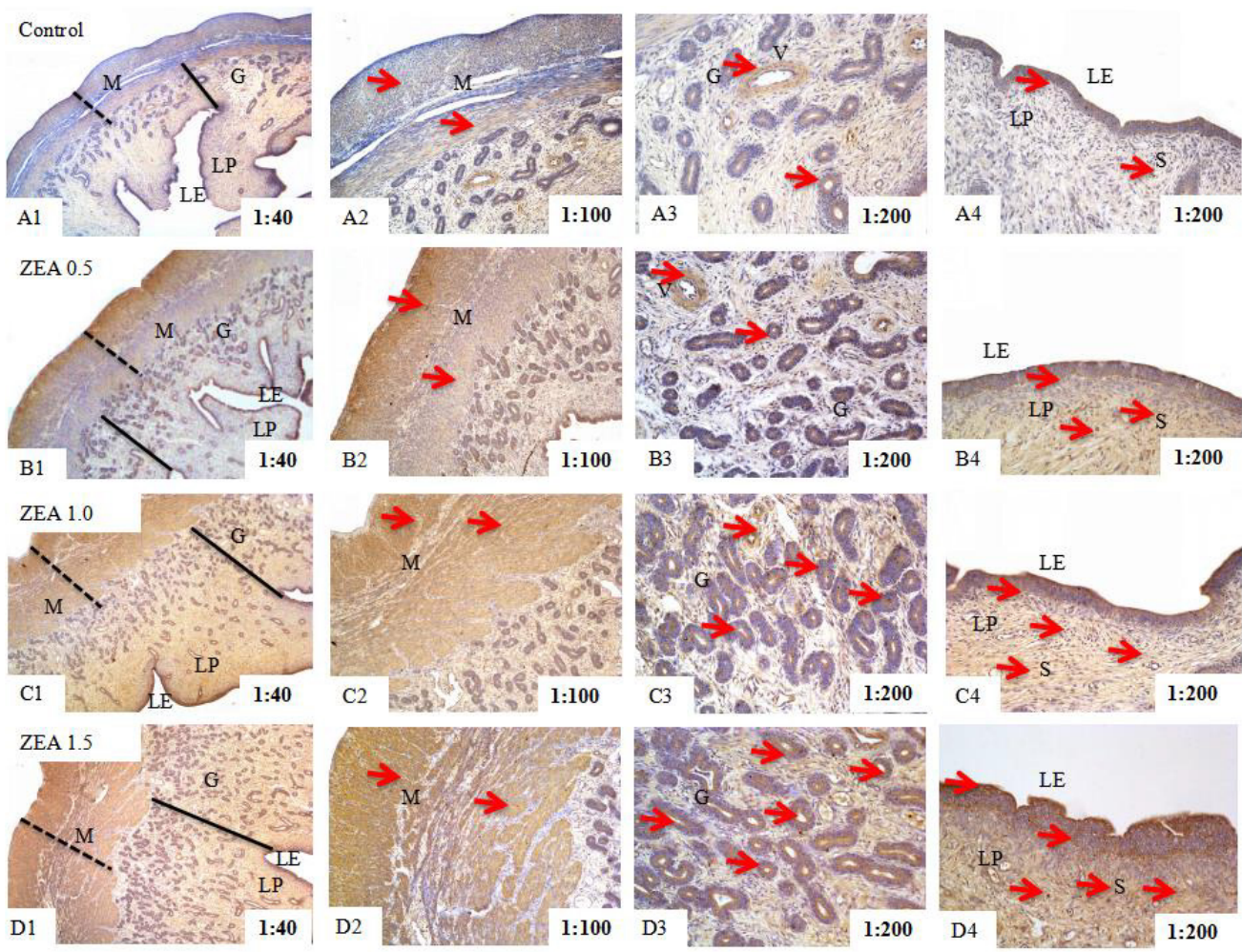

Figure 1. Effects of zearalenone (ZEA) on the growth hormone receptor (GHR) localization in the uteri of post-weaning gilts. Control (A), ZEA0.5 (B), ZEA1.0 (C) and ZEA1.5 (D) represent the control diet with an addition of $0,0.5,1.0$, and $1.5 \mathrm{mg} / \mathrm{kg} Z E A$, and with analyzed ZEA concentrations of $0,0.52 \pm 0.07,1.04 \pm 0.03$, and $1.51 \pm 0.13 \mathrm{mg} / \mathrm{kg}$, respectively. The 1:40, 1:100, and 1:200 represent the view of the samples in 40,100, and 200 times, respectively. The dotted line represents the thickness of myometrium, and the line represents the thickness of endometrial. The arrow represents the immunoreactivity of GHR. LE was luminal epithelium, G was uterine gland, M was myometrium, S was stromal cells, V was vessel, and LP was lamina propria.

\section{Relative mRNA expression of the growth hormone receptor}

The results of the analysis of relative mRNA expression of GHR were consistent with those of immunohistochemistry (Figure 2), with the relative mRNA expression of GHR in the uteri of weaning gilts showing significant linear $(\mathrm{p}<0.001)$ and quadratic $(\mathrm{p}<0.001)$ increases with an increasing level of ZEA. Although the difference between expression levels in the control and the ZEA0.5 treatment was not significant ( $p>0.05$ ), expression in the ZEA1.5 treatment was significantly higher than that in the ZEA1.0 treatment $(\mathrm{p}<0.05)$, and expression in the ZEA1.0 treatment was significantly higher than that in the control and ZEA0.5 treatments $(\mathrm{p}<0.05)$.

\section{Protein expression of the growth hormone receptor}

Western blot analysis was conducted to confirm the specificity of antibodies used. The relative protein expression of GHR in the uteri of weaning gilts increased linearly $(\mathrm{p}<0.001)$ and quadratically $(\mathrm{p}<0.05)$ with the increasing level of ZEA (Figure 3$)$. Although the difference between control and ZEA0.5 treatment was not

Table 4. The effects of zearalenone (ZEA) on the immunoreactive integrated optic density (IOD) of the growth hormone receptor (GHR) in the different parts of the uteri in weaning gilts $\left(\times 10^{3}\right)$

\begin{tabular}{|c|c|c|c|c|c|}
\hline \multicolumn{2}{|l|}{ Items $^{1)}$} & Myometrium & Luminal epithelium & Gland epithelium & Total \\
\hline \multicolumn{2}{|l|}{ Control } & $62.41 \pm 2.18^{d}$ & $42.75 \pm 1.99^{c}$ & $53.02 \pm 2.17^{d}$ & $171.36 \pm 10.52^{c}$ \\
\hline \multicolumn{2}{|l|}{ ZEA0.5 } & $66.53 \pm 3.43^{c}$ & $44.11 \pm 2.59^{c}$ & $59.35 \pm 2.44^{c}$ & $186.81 \pm 12.13^{c}$ \\
\hline \multicolumn{2}{|l|}{ ZEA1.0 } & $72.29 \pm 5.22^{b}$ & $50.93 \pm 2.31^{b}$ & $68.03 \pm 4.28^{b}$ & $230.72 \pm 17.49^{b}$ \\
\hline \multicolumn{2}{|l|}{ ZEA1.5 } & $78.62 \pm 6.88^{\mathrm{a}}$ & $53.74 \pm 2.47^{\mathrm{a}}$ & $77.62 \pm 5.02^{\mathrm{a}}$ & $266.38 \pm 18.64^{a}$ \\
\hline \multirow[t]{3}{*}{$p$-values } & Treatment & 0.018 & 0.027 & 0.023 & 0.011 \\
\hline & Linear & $<0.001$ & $<0.001$ & $<0.001$ & $<0.001$ \\
\hline & Quadratic & 0.012 & 0.016 & 0.014 & 0.007 \\
\hline
\end{tabular}

\footnotetext{
1) Control, ZEA0.5, ZEA1.0, and ZEA1.5 represent the control diet with an addition of $0,0.5,1.0$, and $1.5 \mathrm{mg} / \mathrm{kg}$ ZEA, and with analyzed ZEA concentrations of $0,0.52 \pm 0.07,1.04 \pm 0.03$, and $1.51 \pm 0.13 \mathrm{mg} / \mathrm{kg}$, respectively.

a-d Values with a column with the different letters mean significantly different $(p<0.05)$.
} 


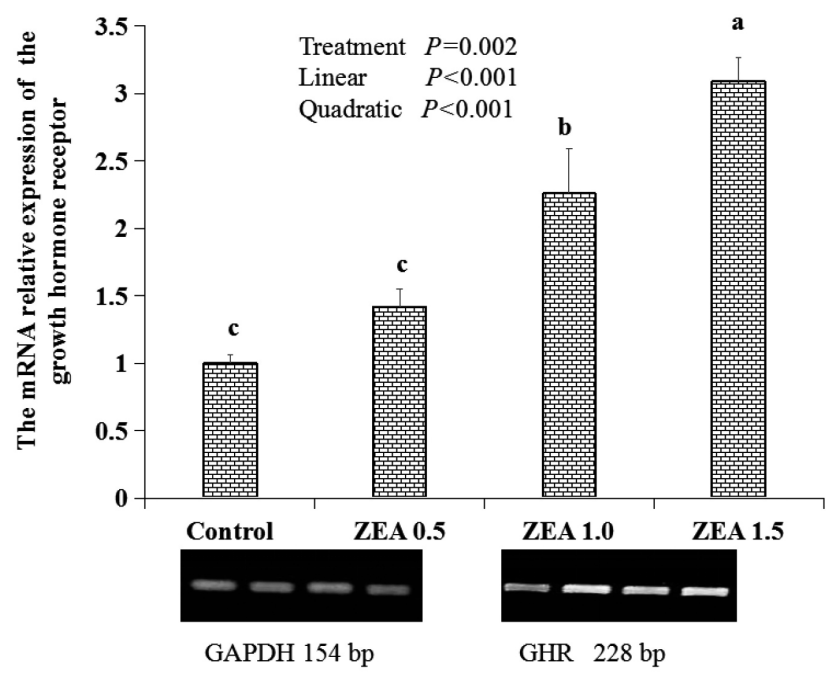

Figure 2. Effects of zearalenone (ZEA) on the relative mRNA expression of the growth hormone receptor (GHR) in the uteri. Control, ZEA0.5, ZEA1.0, and ZEA1.5 represent the control diet with an addition of $0,0.5,1.0$, and $1.5 \mathrm{mg} / \mathrm{kg} Z \mathrm{ZEA}$, and with analyzed ZEA concentrations of $0,0.52 \pm 0.07,1.04 \pm 0.03$, and $1.51 \pm 0.13 \mathrm{mg} / \mathrm{kg}$, respectively.

significant ( $p>0.05)$, protein expression in the ZEA1.5 and ZEA1.0 treatments was significantly higher than that in the ZEA0.5 and control treatments $(\mathrm{p}<0.05)$.

\section{DISCUSSION}

Most of the previous studies on ZEA toxicity have been performed using diets naturally contaminated with certain levels of ZEA [29], however, naturally contaminated diets may also contain other toxins that could have adverse effect on animals. In the present study, we added high-purity ZEA to the diet, based on our previous research results [14,23,24,30,31], to further explore the influence of low doses of ZEA ( 0 to $1.5 \mathrm{mg} / \mathrm{kg}$ ) on GHR localization and GHR mRNA and protein expression in the uteri.

ZEA has estrogenic effects, and mainly affects the reproductive organ of female animals. Fusarium toxins in diets fed to postweaning gilts (ZEA, $0.90 \mathrm{mg} / \mathrm{kg}$, DON, $1.43 \mathrm{mg} / \mathrm{kg}$, FUM, 5.85 $\mathrm{mg} / \mathrm{kg}$ ) have been shown to induce hyperplasia of the glandular endometrium and myometrium [31]. Addition of ZEA (1.1, 2, and $3.2 \mathrm{mg} / \mathrm{kg}$ ) in the diet resulted in a dose-dependent proliferation of myometrial smooth muscle cells in weaning-piglets [32]. The results of the present experiment showed that the thickness of the myometrium and endometrium underwent significant linear and quadratic increases in response to an increasing level of ZEA. The thickness of the myometrium and endometrium in the ZEA1.5 and ZEA1.0 treatments was significantly higher than that in the control. In this regard, the results of the present study are consistent with those of previous studies.

On the basis of an analysis of its chemical structure, it has been predicted that ZEA has potential growth-promoting effects [33].

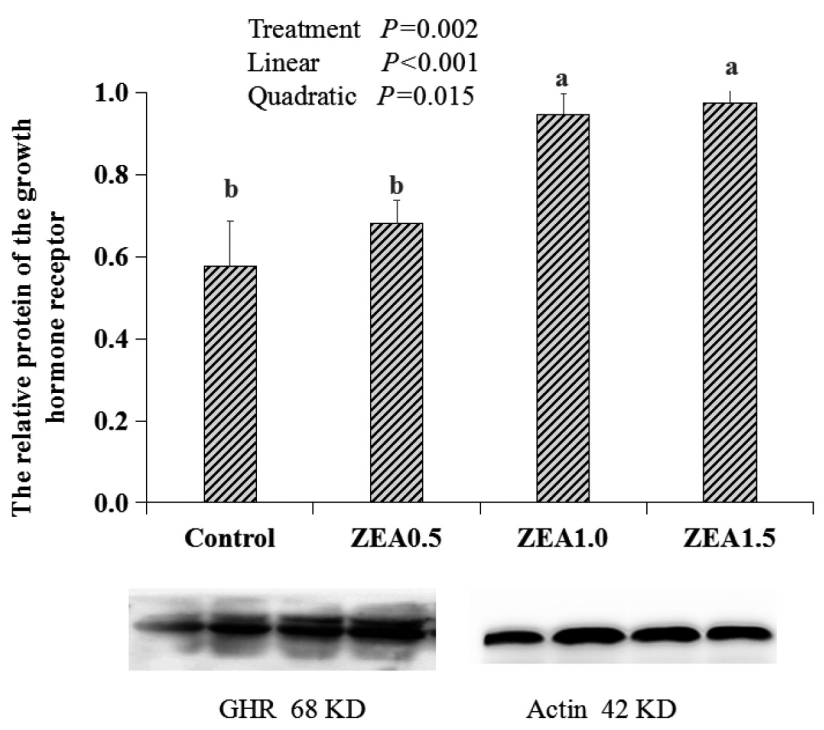

Figure 3. Effects of zearalenone (ZEA) on the relative protein of the growth hormone receptor (GHR) in the uteri. Control, ZEA0.5, ZEA1.0, and ZEA1.5 represent the control diet with an addition of $0,0.5,1.0$, and $1.5 \mathrm{mg} / \mathrm{kg}$ ZEA, and with analyzed ZEA concentrations of $0,0.52 \pm 0.07,1.04 \pm 0.03$, and $1.51 \pm 0.13 \mathrm{mg} / \mathrm{kg}$, respectively.

Zearalenol (ZOL), which is formed following the catalytic hydrogenation of ZEA, assimilated into estrogen. It is accordingly used as a growth promoter in ruminant production [34]. The development of the uteri is closely related to GH [35]. Feeding mice a diet containing 1 and $3 \mathrm{mg} / \mathrm{kg}$ ZEA has been shown to significantly increase uteri weight [36]. Similarly, in the present study, the relative weight of the uteri in the ZEA1.5 and ZEA1.0 treatments was significantly higher than that in the ZEA0.5 and control treatments. The uteri is the site of GH synthesis and action, and expression of GH and GHR are observed in the uteri of a variety of animals [19,37-39]. Knockout of GHR in mice has been shown to delay the date of sexual maturation and to influence reproductive function [40]. Furthermore, analysis of the relative mRNA expression of GHR, insulin-like growth factor I receptor (IGF-IR), and estrogen receptor- $\alpha$ (ER- $\alpha$ ) in the uteri of laying hens has indicated that GH, IGF-I, and estrogen are involved in regulation of the development and function of the uteri [41]. The close relationship between the expression of GHR in the uteri and its growth and development was discovered by Tong [42], who examined the localization and RNA expression of GHR in the uteri of Jining Gray Goats. Immunoreactive substance was mainly localized in the cytoplasm of glandular epithelial cells, smooth muscle cells, vascular endothelial cells, and uterine smooth muscle cells, together with occasional observations of nuclear coloration [42]. The results of our immunohistochemical analysis indicated that GHR immunoreactive substance was mainly localized in the cytoplasm of uterine smooth muscle cells, glandular epithelial cells, luminal epithelial cells, stromal cells, and vascular endothelial cells. In contrast, nuclear staining was rarely observed. A light yellow immunoreactive substance was observed in the control, 
whereas a positive GHR reaction was enhanced and block distribution of yellow and brown immunoreactive substance was observed with an increasing level of ZEA. The localization pattern of GHR observed in the present study differed from that observed by Tong [42], which can presumably be explained by the toxicity of ZEA and the different species of study animals.

The mechanism underlying the effect of ZEA on the development of reproductive organs in animals is primarily related to its estrogenic properties. ZEA and its metabolites are agonists of $\mathrm{ERa}$ (they are observed mainly in the uteri, but not in the ovaries) [43]. The addition of 0.5 to $2 \mathrm{mg} / \mathrm{kg}$ ZEA in the diet has been shown to significantly increase the transcription level of ERa in the uteri and vaginal tissue of gilts, whereas it significantly reduced the transcription level of ER $\beta$, which regulates the development of reproductive organs [44]. The mechanism whereby ZEA acts on sow uteri can probably be explained by the fact that $a-Z O L$ has a high affinity for endometrial estrogen receptors, and competes with estrogen for target tissue receptors to promote the synthesis of DNA, RNA, and protein. [45].

In this study, we investigated GHR, which plays a key role in the growth and development of the uteri. The results showed that the immunoreactive IOD and mRNA and protein expressions of GHR in the uteri of piglets increased linearly with an increasing level of ZEA, which suggests that ZEA can promote uterine development to some extent. It is worth noting that the relative weight of the uteri and mRNA expression of GHR in the ZEA1.0 and ZEA1.5 treatments were significantly higher than those in the ZEA0.5 and control treatments, leading us to speculate that the reproductive toxicity of ZEA is mediated via another growth mechanism. The specific molecular mechanism by which GHR promotes uterine development is accordingly in need of further study.

\section{CONFLICT OF INTEREST}

We certify that there is no conflict of interest with any financial organization regarding the material discussed in the manuscript.

\section{ACKNOWLEDGMENTS}

This research was financed in part by National Nature Science Foundation of China (Project No. 31572441), Natural Science Foundation of Shandong Province (Project No. ZR2017MC049), Agriculture Research System in Shandong Province (SDAIT08-04) and Founds of Shandong "Double Tops".

\section{REFERENCES}

1.Huang LN, Peng SQ, Liu N. Research progress and development on reproductive toxicity of zearalenone. Chin J Contr Endem Dise 2014; 29:181-4.

2.Yazar S, Omurtag GZ. Fumonisins, trichothecenes and zearalenone in cereals. Int J Mol Sci 2008;9:2062-90.

3.Denli M, Blandon JC, Salado S, Guynot ME, Pérez JF. Effect of dietary zearalenone on the performance, reproduction tract and serum biochemistry in young rats. J Appl Anim Res 2017;45:619-22.

4. Yang J, Zhang Y, Wang Y, Cui S. Toxic effects of zearalenone and alpha-zearalenol on the regulation of steroidogenesis and testosterone production in mouse Leydig cells. Toxicol In Vitro 2007;21:558-65.

5.EFSA. Scientific opinion on the risks for public health related to the presence of zearalenone in food. EFSA J 2012;10:1-82.

6.Bandera EV, Chandran U, Buckley B, et al. Urinary mycoestrogens, body size and breast development in New Jersey girls. Sci Total Environ 2011;409:5221-7.

7.Li XY, Zhao LH, Fan Y, et al. Occurrence of mycotoxins in feed ingredients and complete feeds obtained from the Beijing region of China. J Anim Sci Biotechnol 2014;5:37.

8.Selvaraj JN, Wang Y, Zhou L, et al. Recent mycotoxin survey data and advanced mycotoxin detection techniques reported from China: a review. Food Addit Contam A 2015;32:440-52.

9.EFSA. Opinion of the Scientific Panel on Contaminants in the Food Chain on a request from the Commission related to zearalenone as undesirable substance in animal feed. EFSA J 2004;89:1-35.

10. EC. Commission recommendation of 17 August 2006: on the presence of deoxynivalenol, zearalenone, ochratoxin A, T-2 and HT-2 and fumonisin in products intended for animal feeding. Off J European Union 2006;229:7-9.

11. Zou Y, Yang ZB, Yang WR, et al. Effect of purified zearalenone on nutrient digestibility in broilers fed 2 levels of fumonisin from naturally contaminated corn (Zea mays). J Appl Poult Res 2012;21:251-8.

12. Heneweer M, Houtman R, Poortman J, et al. Estrogenic effects in the immature rat uteri after dietary exposure to ethinylestradiol and zearalenone using a systems biology approach. Toxicol Sci 2007; 99:303-14.

13. Cozzini P, Dellafiora L. In silico approach to evaluate molecular interaction between mycotoxins and the estrogen receptors ligand binding domain: a case study on zearalenone and its metabolites. Toxicol Lett 2012;214:81-5.

14. Jiang SZ, Yang ZB, Yang WR, et al. Effects of purified zearalenone on growth performance,organ size,serum metabolites, and oxidative stress in postweaning gilts. J Anim Sci 2011;89:3008-15.

15. Etienne M, Jemmali M. Effects of zearalenone (F2) on estrous activity and reproduction in gilts. J Anim Sci 1982;55:1-10.

16. Yakar S, Isaksson O. Regulation of skeletal growth and mineral acquisition by the GH/IGF-1 axis: Lessons from mouse models. Growth Horm IGF Res 2016;28:26-42.

17. Sun F, Liu Y, Sun H, Tian B. Development and characterization of a novel GHR antibody antagonist, GF185. Int J Biol Macromol 2015; 79:864-70.

18. Zeng C, Liu XL, Wang WM, et al. Characterization of GHRs, IGFs and MSTNs, and analysis of their expression relationships in blunt snout bream, Megalobrama amblycephala. Gene 2014;35:239-49.

19. Gonzalez-Bulnes A, Lopez-Sebastian A, Garcia-Garcia RM, et al. Restoration of endocrine and ovarian function after stopping $\mathrm{GnRH}$ 
antagonist treatment in goats. Theriogenology 2005;63:83-91.

20. Murphy LJ, Bell GI, Friesen HG. Tissue distribution of insulin-like growth factor-I and -II messenger ribonucleic acid in the adult rat. Eedocrinology 1987;120:1279-82.

21. Hafig A, Michel FJ, Simmen FA, Simmen RC. Constitutive expression of uterine receptors for insulin-like growth factor-I during the periimplantation period in the pig. Biol Reprod 1991;45:533-9.

22. Taylor KM, Chen C, Gray AC, Bazer FW, Spencer TE. Expression of messenger ribonucleic acids for fibroblast growth factors 7 and 10 hepatocyte growth factor, and insulin-like growth factors and their receptors in the neonatal ovine uteri. Biol Reprod 2001;64: 1236-46.

23. Chen XX, Yang WR, Zang CY, et al. Effects of fusarium toxins on growth performance, small intestinal disaccharidase activities and antioxidant capacity of weaning piglets. Chin J Anim Nutr 2015;27: 1875-82.

24. Dai ML, Jiang SZ, Yuan XJ, et al. Effects of zearalenone-diet on expression of Ghrelin and PCNA genes in ovaries of post-weaning piglets. Anim Reprod Sci 2016;168:126-37.

25. NRC. Nutrient requirements of swine. Washington, DC, USA: National Academy; 2012.

26. AOAC. Official Methods of Analysis of The AOAC. Rockville, MD, USA: AOAC Int.; 2012.

27. Rivera A, Agnati LF, Horvath TL, et al. Uncoupling protein $2 / 3$ immunoreactivity and theascending dopaminergic and noradrenergic neuronal systems:relevance for volume transmission. Neuroscience 2006;137:1447-61.

28. Livak KJ, Schmittgen TD. Analysis of relative gene expression data using real-time quantitative PCR and the 2 (-Delta $\mathrm{C}(\mathrm{T})$ ) method. Methods 2001;25:402-8.

29. Döll S, Gericke S, Dänicke S, et al. The efficacy of a modified aluminosilicate as a detoxifying agent in Fusarium toxin contaminated maize containing diets for piglets. J Anim Physiol Anim Nutr 2005;89:34258.

30. Yang LJ, Niu QS, Zhang CY, et al. Changes in vulva, serum and oxidative stress index of fusarium toxin in weaning piglets. Swine Ind Sci 2016;33:85-8.

31. Niu QS, Yang WR, Huang LB, et al. Effects of fusarium toxin on vulva, reproductive organ index, distribution and expression of estrogen receptors in uteri of weaning gilts. Chin J Anim Nutr 2016;28:152533.

32. Jiang SZ, Yang ZB, Yang WR, et al. Effect of purified zearalenone with or without modified montmorillonite on nutrient availability, genital organs and serum hormones in post-weaning piglets. Livest Sci 2012; 144:110-8.

33. Powell JW, Raeford S, Lucier GW. Binding properties of zearalenone mycotoxins to hepatic estrogen receptors. Mol Pharmacol 1981;20: 35-42.

34. Alexopoulos C. Association of Fusarium mycotoxicosis with failure in applying an induction of parturition program with PGF2-alpha and oxytocin in sows. Theriogenology 2001;55:1745-57.

35. Ojeda SR, Jameson HE. Developmental patterns of plasma and pituitary growth hormone (GH) in the female rat. Endocrinology 1977; 100:881-9.

36. Becci PJ, KA Voss, Hess FG, et al. Long-term carcinogenicity and toxicity study of zearalenone in the rat. J Appl Toxicol 1982;2:247-54.

37. Schoenmakers I, Kooistra HS, Okkens AC, et al. Growth hormone concentrations in mammary secretions and plasma of the periparturient bitch and in plasma of the neonate. J Reprod Fertil Supple 1997;51:363-7.

38. Maranesi M, Parillo F, Leonardi L, Rebollar PG, et al. Expression of nerve growth factor and its receptors in the uterus of rabbits: functional involvement in prostaglandin synthesis. Domest Anim Endocrin 2016; 56:20.

39. Hrabia A. Growth hormone production and role in the reproductive system of female chicken. Gen Comp Endocrinol 2015;220:112-8.

40. Sosa C, Carriquiry M, Chalar C, et al. Endometrial expression of leptin receptor and members of the growth hormone - insulin-like growth factor system throughout the estrous cycle in heifers. Anim Reprod Sci 2010;122:208-14.

41. Zhu Qian. The expression of GH/IGF-I receptor and estrogen receptor in layers of uteri. Nanjing, China: Nanjing Agric Univ; 2003.

42. Tong HN, Bai S, Wang SY, et al. Developmental changes in the distribution and expression of GHR and IGF-IR in the uteri of Jining Castle Peak sheep. Chin J Anim Vet Sci 2013;44:1392-9.

43. Gajęcka M. The effect of low-dose experimental zearalenone intoxication on the immunoexpression of estrogen receptors in the ovaries of pre-pubertal bitches. Pol J Vet Sci 2012;15:685-91.

44. Wang DF, Zhou HL, Hou GY, Qi DS, Zhang NY. Soybean isoflavone reduces the residue of zearalenone in the muscle and liver of prepubertal gilts. Animal 2013;7:699-703.

45. Alm H, Greising T, Brüssow KP, Torner H, Tieman U. The influence of the mycotoxins deoxynivalenol and zearalenol on in vitro maturation of pig oocytes and in vitro culture of pig zygotes. Toxi In Vitro 2002;16:643-8. 